\title{
Regulation and role of the insulin-like growth factor I system in rat luteal cells
}

\author{
N. Sugino, C. M. Telleria, C. Tessier and G. Gibori* \\ Department of Physiology and Biophysics, University of Illinois at Chicago, Chicago, Illinois 60612-7342, USA
}

\begin{abstract}
The relationship between insulin-like growth factor I (IGF-I), a hormone which has potent metabolic effects and stimulates protein synthesis, and prolactin and oestradiol was examined to investigate a possible mechanism for the luteal cell hypertrophy that is responsible for the increase in size of the corpus luteum. A luteal cell line (GG-CL) derived from large luteal cells of the pregnant rat corpus luteum was used. IGF-I, IGF-I receptor and oestrogen receptor $\beta$ mRNA contents were determined by semiquantitative RT-PCR. The results revealed that prolactin upregulates the expression of IGF-I mRNA in luteal cells, but not that of its receptor. IGF-I had no effect on the expression of its receptor but caused a dose-related increase in the expression of oestrogen receptor $\beta$. Furthermore, whereas IGF-I upregulated oestrogen receptor $\beta$ expression, oestradiol downregulated expression of mRNA for both IGF-I and its receptor. This effect of oestradiol is not mediated through progesterone which is stimulated by oestradiol in the corpus luteum. The developmental studies indicate that mRNA for IGF-I and its receptor are not expressed in tandem throughout pregnancy. Whereas the receptor mRNA is expressed at higher concentrations in early pregnancy, that of its ligand is highly expressed close to parturition. Collectively, the results indicate that prolactin stimulates luteal IGF-I production, which in turn acts on the luteal cell to stimulate expression of oestrogen receptor $\beta$. Luteal cells with increased oestrogen receptor $\beta$ can respond fully to oestradiol, leading to cell hypertrophy.
\end{abstract}

\section{Introduction}

Many tropic hormones act on steroidogenic glands to increase not only steroidogenesis but also the size of their target tissues (Gibori, 1993; Juengel et al., 1995, 1997). In rats, the corpus luteum more than doubles in size with the advance of pregnancy, mainly due to hypertrophy of the large luteal cells (McLean et al., 1992). It is well established that prolactin and luteal oestradiol act in concert to cause hypertrophy of the rat corpus luteum (Alloiteau, 1959). However, the mechanism by which these tropic hormones affect corpus luteum hypertrophy is still unclear. The observation that only the large luteal cell responds to insulinlike growth factor I (IGF-I) stimulation and contains the bulk of the receptors for IGF-I (Parmer et al., 1991) led to the proposal that this growth hormone may mediate, at least in part, prolactin and oestradiol action. IGF-I has potent metabolic effects and stimulates protein synthesis. Expression of IGF-I in the rat liver is stimulated by prolactin (Murphy et al., 1988) and the expression of its receptor is upregulated by oestradiol in a variety of tissues (Murphy

*Correspondence.

Received 6 July 1998. and Ghahary, 1990; Adesanya et al., 1996; Clarke et al., 1997). These observations led to the hypothesis that prolactin stimulates IGF-I expression, whereas oestradiol upregulates expression of the IGF-I receptor. However, administration of oestradiol in vivo caused a marked decrease in IGF-I receptor expression in the corpus luteum of pregnant rats (Parmer et al., 1991). This oestradiol-induced downregulation may be due to progesterone, since oestradiol stimulates progesterone production by the rat corpus luteum and progesterone is known to inhibit expression of the IGF-I receptor and its ligand in several tissues (Papa et al., 1991; Strowitzki et al., 1996; Manikkam and Rajamahendran, 1997). Although oestradiol does not upregulate IGF-I receptor expression, it acts synergistically with IGF-I to stimulate progesterone production by the large luteal cell (Parmer et al., 1991). The fact that oestradiol stimulation depends upon the presence of IGF-I indicates that this growth factor may sensitize the luteal cell to oestradiol action by upregulating oestradiol receptor expression. Therefore, the aims of this investigation in luteal cells were to examine (i) whether oestradiol inhibition of IGF-I and IGF-I receptor expression is due to progesterone, (ii) whether prolactin stimulates IGF-I mRNA expression, and (iii) whether IGF-I, in turn, upregulates expression of the oestradiol receptor. 


\section{Materials and Methods}

\section{Materials}

Progesterone, oestradiol, D-glucose and recombinant human IGF-I were purchased from Sigma Chemical Co. (St Louis, MO). RPMI-1640 medium, antibiotic antimycotic solution, non-essential amino acids and sodium pyruvate were from Mediatech (Washington, DC). Fetal bovine serum (FBS) was from HyClone (Logan, UT). [ $\left.\alpha{ }^{3}{ }^{32} \mathrm{P}\right]$ deoxycytidine triphosphate (dCTP) was from Amersham (Arlington Heights, IL). Culture flasks (25 or $75 \mathrm{~cm}^{2}$ ) were from Becton Dickinson Co. (Franklin Lakes, NJ). Taq DNA polymerase was from Perkin-Elmer Co. (Foster City, CA). Lipofectin and G418 sulfate (Geneticin) were from Life Technologies Inc. (Grand Island, NY).

\section{Animals}

Pregnant Sprague-Dawley rats (day $1=$ sperm positive) purchased from Sasco Animal Labs (Madison, WI) were housed at $24^{\circ} \mathrm{C}$ with a $14 \mathrm{~h}$ light: $10 \mathrm{~h}$ dark photoperiod (lights on 05:00 h-19:00 h) and allowed free access to Purina rat chow and water. The rat care and handling conformed to the NIH guidelines for animal research. The experimental protocol was approved by the Institutional Animal Care and Use Committee.

For the developmental studies, rats were obtained at various stages of pregnancy from days 4 to 22 , the day of parturition and the day after parturition. Corpora lutea were dissected from the ovaries under a stereoscopic microscope. All tissues were frozen in liquid nitrogen and stored at $-80^{\circ} \mathrm{C}$ until RNA isolation.

\section{Cell culture}

The luteal cell line termed GG-CL, which was recently generated in this laboratory (Sugino et al., 1998), was used in this study. Originally, large luteal cells from corpora lutea of rats on day 14 of pregnancy were purified to homogeneity by flow cytometry as reported by Nelson et al. (1992). Cells were infected with a temperature sensitive simian virus 40 (SV-40 tsA209) according to Chou (1985). Transformed cells were maintained at the permissive temperature $\left(33^{\circ} \mathrm{C}\right)$ until colonies were identified. Several colonies of the transformed cells were isolated and passaged. One clone, designated GGCL cells, was used in this study. GG-CL cells were cultured in 25 or $75 \mathrm{~cm}^{2}$ flasks with the incubation medium (RPMI-1640 medium containing $2 \times$ antibiotic antimycotic solution, $1 \times$ non-essential amino acids, $1 \times$ sodium pyruvate, $0.5 \%(\mathrm{w} / \mathrm{v})$ D-glucose and $10 \%$ FBS) at permissive $\left(33^{\circ} \mathrm{C}\right)$ and nonpermissive $\left(39^{\circ} \mathrm{C}\right)$ temperatures under an atmosphere of $5 \%$ $\mathrm{CO}_{2}: 95 \%$ air. The FBS used in this study was heatinactivated. GG-CL cells show the normal morphological differentiated phenotype similar to that of primary luteal cells at $39^{\circ} \mathrm{C}$ and express many genes that are characteristic of primary cells, although they do not produce progesterone (Sugino et al., 1998).

\section{Transfection of GG-CL cells with the prolactin receptor}

GG-CL cells transfected stably with the long form of the prolactin receptor were used for the experiments with prolactin. Transfection was performed according to the procedure of Felgner et al. (1987) with a slight modification as described by Sugino et al. (1998). Briefly, GG-CL cells were plated in six-well Falcon dishes and grown at $33^{\circ} \mathrm{C}$ to $33 \%$ confluence in RPMI-1640 medium containing 5\% FBS. Cells were washed with serum-free medium with no antibiotics and were transfected using Lipofectin according to the manufacturer's protocol. The cells were transfected with $10 \mu \mathrm{g}$ of the expression vector pMT2poly containing the long form of the prolactin receptor cDNA and with pSV2neo vector. After transfection, the medium was replaced with growth medium containing 5\% FBS and antibiotics and incubated for $48 \mathrm{~h}$. After $48 \mathrm{~h}$, the medium was again replaced with fresh growth medium and treated with $100 \mu \mathrm{g} \mathrm{G418}$ sulfate $\mathrm{ml}^{-1}$. Addition of G418 sulfate was continued once every 2 days until G418 sulfate resistant colonies were identified. These colonies were picked and cultured in the growth medium containing 5\% FBS until the cells were confluent. For identification of successful stable transfection with prolactin receptor, cells were grown and passaged several times. Prolactin receptor mRNA expression in these cells was determined by RT-PCR using prolactin receptor specific primers as reported by Sugino et al. (1998).

\section{Treatment of GG-CL cells}

GG-CL cells were cultured at $33^{\circ} \mathrm{C}$ until $50 \%$ confluent and then at $39^{\circ} \mathrm{C}$ for 2 days to examine the effects of IGF-I on oestrogen receptor $\beta$ mRNA expression and the effects of oestradiol or progesterone on IGF-I and IGF-I receptor mRNA expression. Cells were then treated with either IGF-I, oestradiol or progesterone. To examine the effect of prolactin in GG-CL cells GG-CL cells transfected with prolactin receptor were cultured at $33^{\circ} \mathrm{C}$ until $50 \%$ confluent and then at $39^{\circ} \mathrm{C}$ for 2 days. Cells were then treated with ovine prolactin (NIDDK oPRL-20, $31 \mathrm{iu} \mathrm{mg}^{-1}$ ). Cells were cultured in the presence of $1 \%$ FBS during the treatment at $39^{\circ} \mathrm{C}$ as serum is necessary for survival at $39^{\circ} \mathrm{C}$. Changes in morphology were not observed after hormonal treatments in GG-CL cells and in cells transfected with prolactin receptor. After culture, the cells were washed with PBS several times and stored at $-80^{\circ} \mathrm{C}$ for RNA isolation.

\section{Isolation of total RNA and RT-PCR}

Total RNA was isolated from corpora lutea by homogenization in guanidinium thiocyanate and centrifugation through a caesium chloride cushion (Chirgwin et al., 1979), whereas total RNA from the cultured cells was isolated by the guanidinium isothiocyanatephenol-chloroform extraction procedure (Chomczynski and Sacchi, 1987). For mRNA analysis by RT-PCR, oligonucleotide primers for IGF-I (5'-CACATCTCTTCTACCTGGCA-3' and 5'-TGAGTCTTGGGCATGTCAGT-3'), IGF-I receptor 
(5'-TCCACCATAGACTGGTCTCT-3' and 5'-ACGAAGCCATCTGAGTCACT- $\left.3^{\prime}\right)$ and oestrogen receptor $\beta$ ( $5^{\prime}$-GCCAATCATGTGCACCAGTTCCTT- $3^{\prime}$ and $5^{\prime}$-AAAGCCAAGAGAAACGGTGGGCAT-3') were designed on the basis of each cDNA sequence (Roberts et al., 1987; Werner et al., 1989; Kuiper et al., 1996). Each reaction also included primers (5'CTGAAGGTCAAAGGGAATGTG-3' and 5'-GGACAGAGTCTTGATGATCTC-3') to amplify ribosomal protein L19 or primers (5'-CGTTCACCTTGATGAGCCCATT- 3 ' and 5'TCCAAGGGTCCGCTGCAGTC-3') to amplify ribosomal protein S16. Both L19 and S16 were used as internal controls (Chan et al., 1987; Batra et al., 1991). The predicted sizes of the PCR-amplified products were $319 \mathrm{bp}$ for IGF-I, $434 \mathrm{bp}$ for IGF-I receptor, $203 \mathrm{bp}$ for oestrogen receptor $\beta, 194 \mathrm{bp}$ for L19, and $100 \mathrm{bp}$ for S16. Total RNA ( $3 \mu \mathrm{g})$ was reverse transcribed at $42^{\circ} \mathrm{C}$ in a $20 \mu \mathrm{l}$ reaction mixture $(1 \times \mathrm{PCR}$ buffer, $2.5 \mathrm{mmol}$ deoxynucleoside triphosphates $1^{-1}, 5 \mathrm{\mu mol}$ random hexamer primers $\mathrm{l}^{-1}, 1.5 \mathrm{mmol} \mathrm{MgCl}_{2} \mathrm{l}^{-1}$, and $200 \mathrm{U}^{-1}$ Moloney murine leukaemia virus reverse transcriptase (Life Technologies Inc., Grand Island, NY)). For PCR amplification, a mixture containing oligonucleotide primers $(50 \mathrm{pmol}),\left[\alpha-{ }^{32} \mathrm{P}\right] \mathrm{dCTP}$ $\left(2 \mu \mathrm{Ci}\right.$ at $\left.3000 \mathrm{Ci} \mathrm{mmol}^{-1}\right)$, and Taq DNA polymerase $(2.5 \mathrm{U})$ was added to each reaction. The total volume was increased to $90 \mu \mathrm{l}$ with $1 \times$ PCR buffer, and the samples were overlaid with mineral oil. Amplifications were carried out for 20 cycles with $62^{\circ} \mathrm{C}$ annealing temperature for IGF-I, for 20 cycles with $63^{\circ} \mathrm{C}$ annealing temperature for IGF-I receptor, and for 30 cycles with $65^{\circ} \mathrm{C}$ annealing temperature for oestrogen receptor $\beta$ in a Perkin-Elmer Cetus thermal cycler. The conditions were such that amplification of the product was in the exponential phase, and the assay was linear with respect to the amount of input RNA. Reaction products were separated by electrophoresis on an $8 \%(\mathrm{w} / \mathrm{v})$ polyacrylamide non-denaturing gel. Each RT-PCR reaction included L19 or S16 ribosomal protein mRNA primers to normalize the data. After autoradiography, data were quantified using a PhosphorImager (Molecular Dynamics, Sunnyvale, CA).

\section{Statistical analysis}

Data were examined by ANOVA and Duncan's new multiple range test. Differences were considered to be significant if $P<0.05$.

\section{Results}

\section{Effects of oestradiol and progesterone on IGF-I and IGF-I receptor $m R N A$ expression}

GG-CL cells were cultured in the presence of either oestradiol or progesterone to examine whether the oestradiol inhibition of IGF-I and IGF-I receptor observed in vivo (Parmer et al., 1991) also occurs in cell culture and whether the oestradiol effect is mediated by progesterone. Oestradiol treatment caused a marked inhibition in both IGF-I and IGF-I receptor mRNA expression despite the fact that these cells do not produce progesterone (Fig. 1). In addition, progesterone treatment of GG-CL cells had no inhibitory effect on the expression of IGF-I and IGF-I receptor mRNA (Fig. 2).
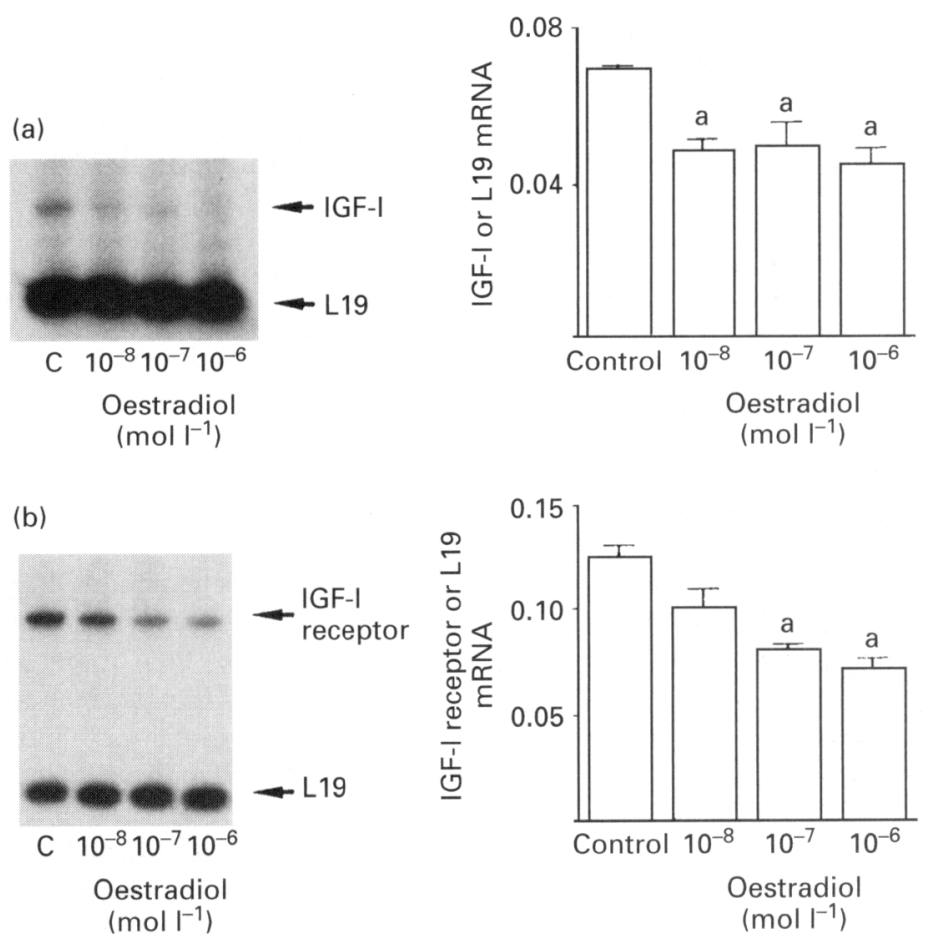

Fig. 1. Effect of oestradiol on (a) insulin-like growth factor I (IGF-I) and (b) IGF-I receptor mRNA expression in a luteal cell line (GG-CL) derived from the large luteal cells of the pregnant rat corpus luteum. GG-CL cells were incubated with oestradiol $\left(10^{-8}, 10^{-7}\right.$ and $10^{-17}$ mol $\left.1^{-1}\right)$ for $8 \mathrm{~h}$ at $39^{\circ} \mathrm{C}$. Total RNA was isolated and subjected to RT-PCR. The quantification data are mean \pm SEM of three different experiments. C, control. a, $P<0.01$ versus control. 

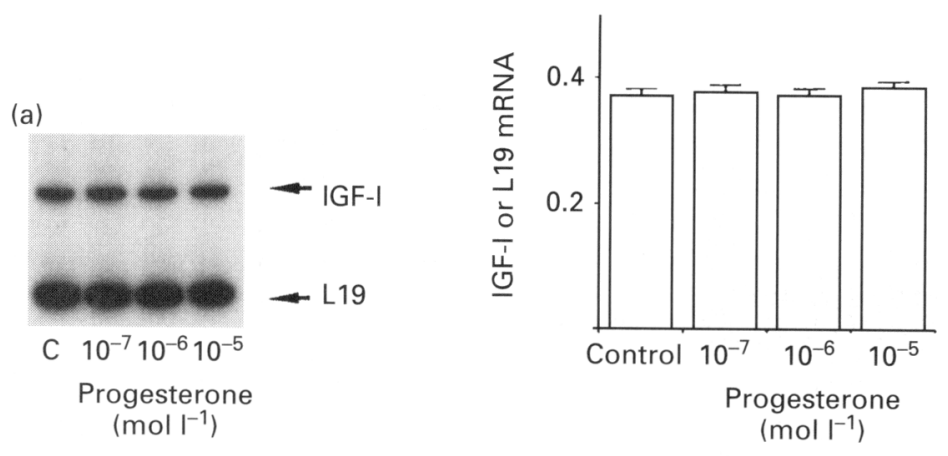

(b)

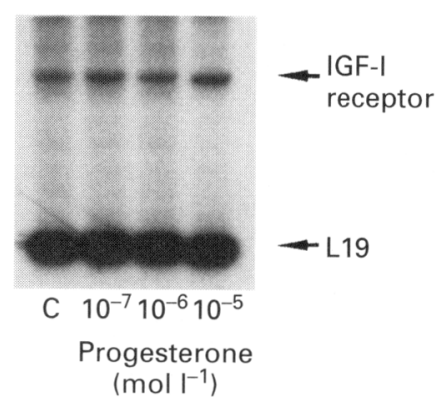

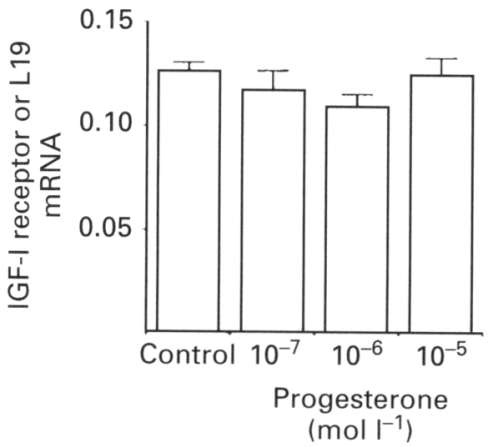

Fig. 2. Effect of progesterone on (a) insulin-like growth factor I (IGF-I) and (b) IGF-I receptor mRNA expression in a luteal cell line (GG-CL) derived from the large luteal cells of the pregnant rat corpus luteum. GG-CL cells were incubated with progesterone $\left(10^{-7}, 10^{-6}\right.$ and $10^{-5}$ mol $\left.1^{-1}\right)$ for $24 \mathrm{~h}$ at $39^{\circ} \mathrm{C}$. Total RNA was isolated and subjected to RT-PCR. The quantification data are mean \pm SEM of three different experiments.

\section{Effects of prolactin on IGF-I and IGF-I receptor mRNA expression}

The effect of prolactin on IGF-I and IGF-I receptor mRNA expression was examined by incubating GG-CL cells expressing the prolactin receptor with different concentrations of prolactin. Prolactin stimulated the expression of IGF-I mRNA significantly, but not that of IGF-I receptor (Fig. 3).

\section{Effects of IGF-I on oestrogen receptor $\beta$ and IGF-I receptor mRNA expression}

GG-CL cells were incubated with IGF-I at different concentrations to examine the effects of IGF-I on oestrogen receptor $\beta$ mRNA. The result indicates that IGF-I elicits a dose-dependent increase in oestrogen receptor $\beta$ expression (Fig. 4). Urban et al. (1994) reported that IGF-I downregulates IGF-I receptor mRNA expression in pig granulosa cells. Thus, the effect of IGF-I on IGF-I receptor mRNA expression was also examined. IGF-I had no effect on IGF-I receptor mRNA expression in GG-CL cells (data not shown).

Developmental changes in IGF-I and IGF-I receptor mRNA concentrations in the corpus luteum throughout pregnancy and after parturition

Corpora lutea were isolated on different days of pregnancy, the day of parturition, or the day after parturition to investigate the developmental changes in IGF-I and IGF-I receptor mRNA. IGF-I mRNA is constitutively expressed in the corpus luteum throughout pregnancy, but increases significantly from day 20 (Fig. 5a). In contrast, the concentration of IGF-I receptor mRNA reaches a peak at day 9 , and gradually decreases thereafter (Fig. 5b).

\section{Discussion}

In pregnant rats, two luteal cell populations, small and large luteal cells, form the corpus luteum (Gibori, 1993). Although the origin of the two luteal cell populations is uncertain, it is hypothesized that luteal cell size does not depend on follicular origin, but rather on the responsiveness of individual luteal cells to growth signals (Gibori, 1993). It has been reported that large luteal cells respond to IGF-I stimulation and contain the bulk of the IGF-I receptors (Parmer et al., 1991), and that it is this population that undergoes hypertrophy during the development of the corpus luteum (McLean et al., 1992). The results of the present study indicate a possible mechanism for luteal cell hypertrophy. Prolactin stimulates luteal production of IGF-I, which acts on luteal cells expressing the IGF-I receptor, such as the large luteal cells, to stimulate oestradiol receptor expression. Greater numbers of oestrogen receptors may allow the cells to respond fully to oestradiol stimulation, leading to cell hypertrophy and an increase in the size of the corpus luteum.

Oestradiol upregulates mRNA expression for both IGF-I and IGF-I receptor in non-steroidogenic tissues (Murphy and 
(a)
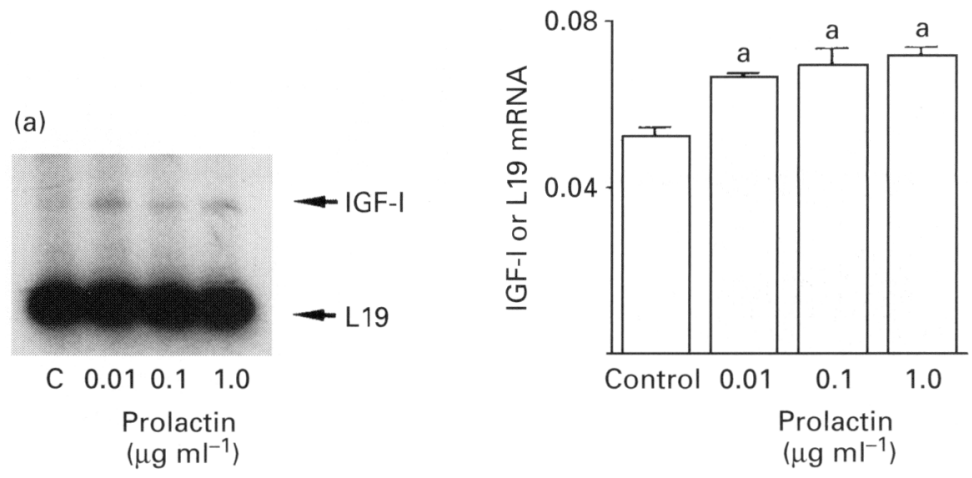

(b)
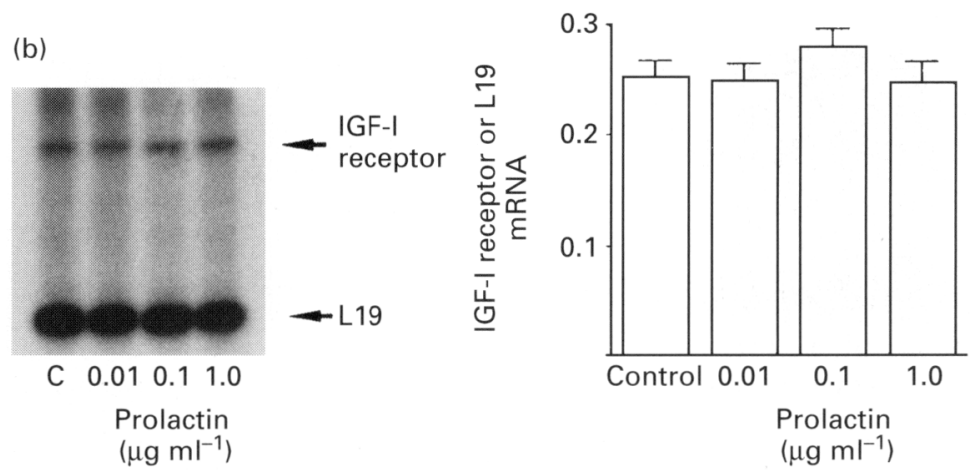

Fig. 3. Effect of prolactin on (a) insulin-like growth factor I (IGF-I) and (b) IGF-I receptor mRNA expression in a luteal cell line (GG-CL) derived from the large luteal cells of the pregnant rat corpus luteum. GG-CL cells stably transfected with the long form of the prolactin receptor were incubated with prolactin $\left(0.01,0.1\right.$ and $\left.1.0 \mu \mathrm{g} \mathrm{ml}^{-1}\right)$ for $8 \mathrm{~h}$ at $39^{\circ} \mathrm{C}$. Total RNA was isolated and subjected to RT-PCR. The quantification data are mean \pm SEM of three different experiments. $a, P<0.01$ versus control.
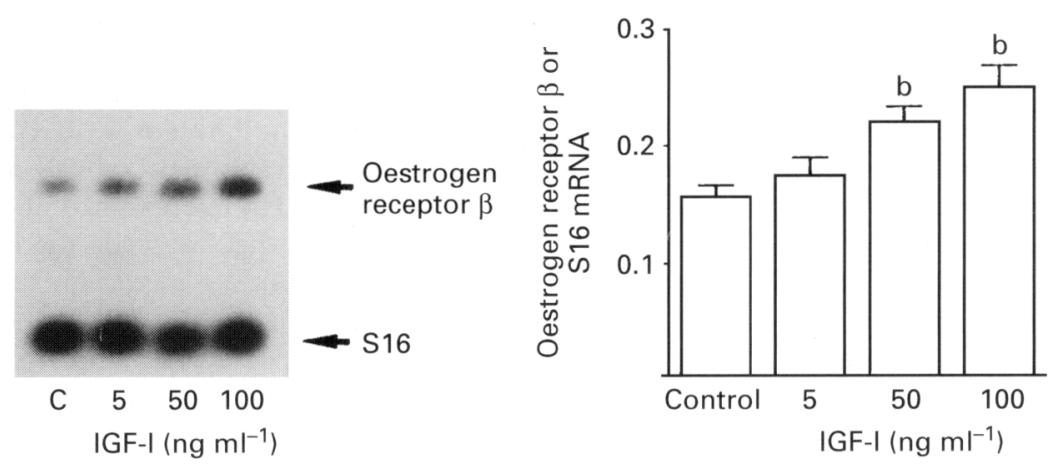

Fig. 4. Effect of insulin-like growth factor I (IGF-I) on oestrogen receptor $\beta$ mRNA expression in a luteal cell line (GG-CL) derived from the large luteal cells of the pregnant rat corpus luteum. GG-CL cells were incubated with recombinant human IGF-I $\left(5,50\right.$ and $\left.100 \mathrm{ng} \mathrm{ml}^{-1}\right)$ for $8 \mathrm{~h}$ at $39^{\circ} \mathrm{C}$. Total RNA was isolated and subjected to RT-PCR. The quantification data are mean \pm SEM of three different experiments. $b, P<0.05$ versus control.

Ghahary, 1990; Adesanya et al., 1996; Clarke et al., 1997), but downregulates expression of both mRNAs in the rat corpus luteum (Parmer et al., 1991). A luteal cell line (GG-CL) derived from the large luteal cells of the pregnant rat corpus luteum (Sugino et al., 1998) was used to examine whether oestradiol-induced downregulation is mediated by progesterone. GG-CL cells express IGF-I, IGF-I receptor, oestradiol receptor $\beta$ and the glucocorticoid receptor that serves as a receptor for progesterone in the rat corpus luteum (Zilberstein et al., 1991; Sugino et al., 1997, 1998; Telleria et al., 1998). The advantage of GG-CL cells is that they do not secrete progesterone (Sugino et al., 1997, 1998) and thus the possibility that oestradiol action is mediated by progesterone is eliminated. Another advantage of these cells is that they are responsive to progesterone (Sugino et al., 1997). The results of the present study indicate that oestradiol downregulation of IGF-I and IGF-I receptor mRNA expression in luteal cells is not mediated by progesterone.

Parmer et al. (1991) reported a synergistic effect of IGF-I and oestradiol on progesterone production by large luteal cells. The present study indicates that this synergistic effect involves, at least in part, IGF-I-stimulated oestrogen receptor 

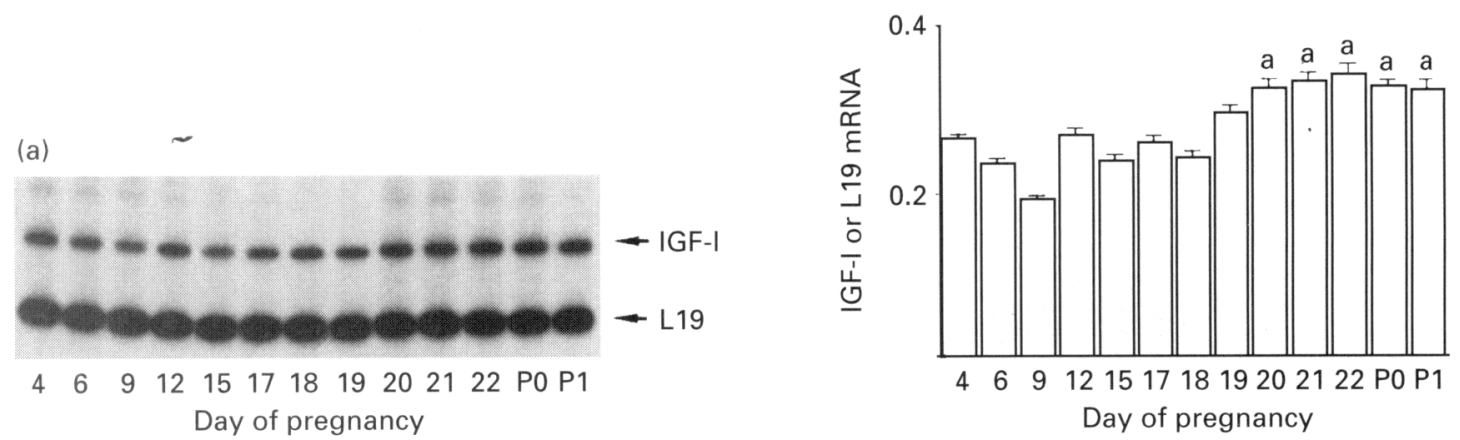

(b)

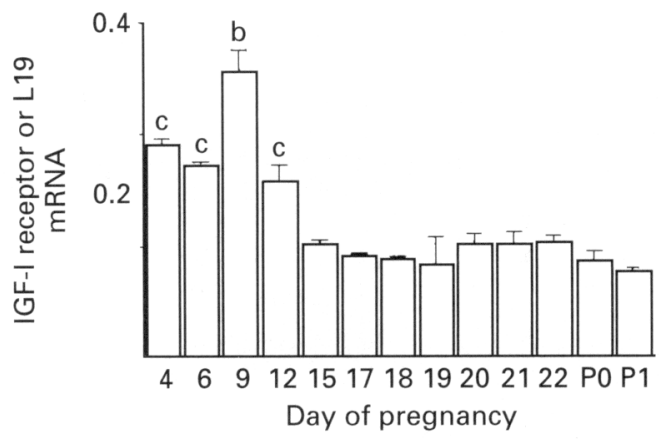

Fig. 5. Developmental expression of (a) insulin-like growth factor I (IGF-I) and (b) IGF-I receptor mRNA in the rat corpus luteum throughout pregnancy and after parturition. Total RNA isolated on each day was subjected to RT-PCR. RNA samples were collected from more than three animals on each day and in each experiment. $\mathrm{P} 0$ and $\mathrm{P} 1$ are day 0 and day 1 post partum, respectively. The quantification data are mean \pm SEM of three different experiments. $a, P<0.01$ versus day $4-18 ; b, P<0.01$ versus day 4,6 and $12 ; c, P<0.01$ versus day $15-P 1$.

mRNA expression. Therefore, IGF-I may sensitize luteal cells to oestradiol action by upregulating oestradiol receptor expression. This is supported by the finding that ligands for IGF-I receptor modulate the regulation of oestrogen receptor expression in a breast cancer cell line (Clayton et al., 1997).

Prolactin is known to enhance overall protein synthesis at the translational level (Albarracin et al., 1994) and to upregulate the expression of the oestradiol receptor (Telleria et al., 1998). The results of the present study show that prolactin upregulates IGF-I mRNA expression and that IGF-I stimulates oestradiol receptor expression in luteal cells. This indicates that prolactin stimulation of both protein synthesis and oestradiol receptor expression is mediated, at least in part, by IGF-I.

The present study also examined the developmental changes in IGF-I and IGF-I receptor mRNA in the corpus luteum throughout pregnancy. The results reveal that mRNA for IGF-I and its receptor are not expressed in tandem. Whereas concentrations of IGF-I mRNA increase substantially at the end of pregnancy, beginning from day 20 , concentrations of IGF-I receptor mRNA are higher in early pregnancy and decrease from day 12. Tamada et al. (1995) reported that expression of IGF-I mRNA is high at the end of pregnancy. In rats, prolactin and placental lactogens (rPL-I and -II) secreted by the placenta may be responsible for maintaining the concentration of IGF-I mRNA until day 20. However, these hormones are not responsible for the increase in IGF-I mRNA expression after day 20 since, at this stage, a decrease in prolactin receptor expression occurs in the corpus luteum, which becomes non-responsive to prolactin and placental lactogen stimulation (Telleria et al., 1997). The increase in IGFI expression at the end of pregnancy and after parturition, at a time when the corpus luteum is undergoing both functional and structural luteolysis, is intriguing. However, the increase in IGF-I binding protein 3 in corpora lutea undergoing luteolysis (Erickson et al., 1993) probably neutralizes the action of IGF-I. The expression of IGF-I receptor mRNA in the corpus luteum appears to be the opposite to that of IGF-I. However, the decline in the number of receptors does not appear to be induced by IGF-I, since IGF-I had no effect on IGF-I receptor expression, and it may be due to oestradiol produced locally by the corpus luteum. Oestradiol concentrations in the corpus luteum increase in the second half of pregnancy (Taya and Greenwald, 1981) and oestradiol inhibits IGF-I receptor expression both in vivo (Parmer et al., 1991) and in vitro, as observed in the present study.

In summary, the results of the present study indicate that prolactin stimulates the expression of IGF-I mRNA in luteal cells, which in turn upregulates the expression of oestradiol receptor $\beta$. The results also indicate that there is a feedback mechanism between IGF-I and oestradiol action. Whereas IGF-I stimulates oestradiol receptor expression, oestradiol downregulates the concentration of the IGF-I receptor and its ligand.

The authors are grateful to the National Institute of Diabetes and Digestive and Kidney Diseases and National Hormone and Pituitary Program (NIH) for the ovine prolactin. They also thank Linda Alaniz for her photographic work and Rosemary Clepper for animal care. The expression vectors pMT2poly and pSV2neo were generously 
provided by Daniel Linzer, Northwestern University, Chicago, IL. This work was supported by NIH HD-11119 and FIC 1F05TW05241. G. Gibori was the recipient of an NIH Merit Award (HD11119).

\section{References}

Adesanya OO, Zhou J and Bondy CA (1996) Sex steroid regulation of insulinlike growth factor system gene expression and proliferation in primate myometrium Journal of Clinical Endocrinology and Metabolism 81 1967-1974

Albarracin CT, Palfrey HC, Duan WR, Rao MC and Gibori G (1994) Prolactin regulation of the $\mathrm{Ca}^{2+} /$ calmodulin-dependent protein kinase III-elongation factor 2 system in the rat corpus luteum Journal of Biological Chemistry 269 7772-7776

Alloiteau JJ (1959) Hypertrophie du corps jaune chez la ratte a antehypophyse greffee dans le rein et recevant du propionate de testosterone. Secretion d'un oestrogene par le corps jaune Current Research of Academic Science (Paris) 249 1718-1724

Batra SK, Metzgar RS and Hollingsworth MA (1991) Molecular cloning and sequence analysis of human ribosomal protein S16 Journal of Biological Chemistry 266 6830-6833

Chan YL, Lin A, McNally J, Pelleg D, Meyuhas O and Wool I (1987) The primary structure of rat ribosomal protein L19 Journal of Biological Chemistry 262 1111-1115

Chirgwin JJ, Przbyla AE, MacDonalds RJ and Rutter WJ (1979) Isolation of biologically active ribonucleic acid from sources enriched in ribonuclease Biochemistry 18 5294-5299

Chomczynski P and Sacchi N (1987) Single step method of RNA isolation by acid guanidinium thiocyanate-phenol-chloroform extraction Analytical Biochemistry 162 156-159

Chou JY (1985) Establishment of rat liver lines and characterization of their metabolic and hormonal properties: use of temperature sensitive SV-40 virus Methods in Enzymology 109 385-396

Clarke RB, Howell A and Anderson E (1997) Type I insulin-like growth factor receptor gene expression in normal human breast tissue treated with oestrogen and progesterone British Journal of Cancer 75 251-257

Clayton SJ, May FEB and Wesley BR (1997) Insulin-like growth factors control the regulation of oestrogen and progesterone receptor expression by oestrogens Molecular and Cellular Endocrinology 128 57-68

Erickson GF, Nakatani A, Ling N and Shimasaki S (1993) Insulin-like growth factor binding protein-3 gene expression is restricted to involuting corpora lutea in rat ovaries Endocrinology 133 1147-1157

Felgner PL, Gadek TR, Holm M, Roman R, Chan HW, Wenz M, Northrop JP, Ringold GM and Danielsen M (1987) Lipofection: a highly efficient, lipidmediated DNA-transfection procedure Proceedings National Academy of Sciences USA 84 7413-7417

Gibori G (1993) The corpus luteum of pregnancy. In The Ovary pp 261-317 Eds EY Adashi and PCK Leung. Raven Press, New York

Juengel JL, Nett TM, Tandeski TR, Eckery DC, Sawyter HR and Niswender GD (1995) Effect of luteinizing hormone and growth hormone on luteal development in hypophysectomized ewes Endocrine $3323-326$

Juengel JL, Nett TM, Anthony RV and Niswender GD (1997) Effects of luteotrophic and luteolytic hormones on expression of mRNA encoding insulin-like growth factor I and growth hormone receptor in the ovine corpus luteum Journal of Reproduction and Fertility 110 291-298

Kuiper GGJM, Enmark E, Peltp-Huikko M, Nilsson S and Gustafsson J-A (1996) Cloning of a novel estrogen receptor expressed in rat prostate and ovary Proceedings National Academy of Sciences USA 93 5925-5930

McLean MP, Nelson SE, Billheimer JT and Gibori G (1992) Differential capacity for cholesterol transport and processing in large and small rat luteal cells Endocrinology 131 2203-2212
Manikkam M and Rajamahendran R (1997) Progesterone-induced atresia of the proestrous dominant follicle in the bovine ovary: changes in diameter, insulin-like growth factor system, aromatase activity, steroid hormones, and apoptotic index Biology of Reproduction 57 580-587

Murphy LJ and Ghahary A (1990) Uterine insulin-like growth factor-1: regulation of expression and its role in estrogen-induced uterine proliferation Endocrine Reviews 11 443-453

Murphy LJ, Tachibana K and Friesen HG (1988) Stimulation of hepatic insulin-like growth factor-I gene expression by ovine prolactin: evidence for intrinsic somatogenic activity in the rat Endocrinology 122 2027-2033

Nelson SE, McLean MP, Jayatilak PG and Gibori G (1992) Isolation, characterization, and culture of cell subpopulations forming the pregnant rat corpus luteum Endocrinology 130 954-966

Papa V, Harnmann KP, Rosenthal SM, Maddux BA, Siiteri PK and Goldfine ID (1991) Progestin induced down-regulation of insulin-like growth factor-I (IGF-I) receptors in human breast cancer cell: potential autocrine role of IGF-II Molecular Endocrinology 5 709-717

Parmer TG, Roberts CT, LeRoith D, Jr, Adashi EY, Kahn I, Solan N, Nelson S, Zilberstein M and Gibori G (1991) Expression, action, and steroidal regulation of insulin-like growth factor-I (IGF-I) and IGF-I receptor in the rat corpus luteum: their differential role in the two cell populations forming the corpus luteum Endocrinology 129 2924-2932

Roberts CT, Jr, Lasky SR, Lowe WL, Jr, Seaman WT and LeRoith D (1987) Molecular cloning of rat insulin-like growth factor I complementary deoxyribonucleic acids: differential messenger ribonucleic acid processing and regulation by growth hormone in extrahepatic tissues Molecular Endocrinology $1243-248$

Strowitzki T, Singer GAM, Retting I and Capp E (1996) Characterization of receptors for insulin-like growth factor type I on cultured human endometrial stromal cells: downregulation by progesterone Gymecological Endocrinology $10229-240$

Sugino N, Telleria CM and Gibori G (1997) Progesterone inhibits $20 \alpha$ hydroxysteroid dehydrogenase $(20 \alpha-H S D)$ gene expression in the rat corpus luteum through the glucocorticoid receptor Endocrinology 138 $4497-4500$

Sugino N, Zilberstein M, Srivastava RK, Telleria CM, Nelson SE, Risk M, Chou JY and Gibori G (1998) Establishment and characterization of a simian virus 40 -transformed temperature sensitive rat luteal cell line Endocrinology 139 1936-1942

Tamada H, Kitashin H, Sawada T and Mori J (1995) Expression of insulin-like growth factor-I mRNA in rat luteal tissue increases with functional regression of the corpus luteum Prostaglandins 50 151-160

Taya $\mathrm{K}$ and Greenwald GS (1981) In vivo and in vitro ovarian steroidogenesis in the pregnant rat Biology of Reproduction 25 683-692

Telleria CM, Parmer TG, Zhong L, Clarke DL, Albarracin CT, Duan WR, Linzer DIH and Gibori G (1997) The different forms of the prolactin receptor in the rat corpus luteum: developmental expression and hormonal regulation in pregnancy Endocrinology 138 4812-4820

Telleria CM, Zhong L, Deb S, Srivastava RK, Park KS, Sugino N, Park-Sarge OK and Gibori G (1998) Differential expression of the estrogen receptor- $\alpha$ and $\beta$ in the rat corpus luteum of pregnancy: regulation by prolactin and placental lactogens Endocrinology 139 2432-2442

Urban RJ, Boenburg YH, Nagamani $\mathbf{M}$ and Peirce J (1994) Dexamethasone potentiates IGF-I actions in porcine granulosa cells American foumal of Physiology 267 E115-E123

Werner H, Woloschak M, Adamo M, Shen-Orr Z, Roberts CT, Jr and LeRoith D (1989) Developmental regulation of rat insulin-like growth factor I receptor gene Proceedings National Academy of Sciences USA 86 7451-7455

Zilberstein M, Parmer TG, Nelson S, McLean MP, Harlow L, Gleicher N, Chou JY and Gibori G (1991) Expression of IGF-I and IGF-I receptor gene in transformed luteal cells. In Signaling Mechanism and Gene Expression in the Ovary pp 297-303 Ed. G Gibori. Serono Symposia, USA. 